\title{
Graphite morphologies from the Borrowdale deposit (NW England, UK): Raman and SIMS data
}

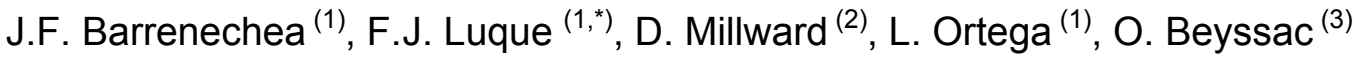 \\ and M. Rodas ${ }^{(1)}$
}

(1) Dpto. Cristalografía y Mineralogía, Facultad de Geología, Universidad Complutense de Madrid, 28040 Madrid, Spain.

(2) British Geological Survey, Murchison House, West Mains Road, Edinburgh EH9 3LA, UK.
(3) Laboratoire de Géologie, CNRS, Ecole Normale Supérieure, 24 rue Lhomond, 75005 Paris, France.

$\left.{ }^{*}\right)$ Corresponding author: jluque@geo.ucm.es

\section{Abstract}

Graphite in the Borrowdale (Cumbria, UK) deposit occurs as large masses within mineralized pipe-like bodies, in late graphite-chlorite veins, and disseminated through the volcanic host rocks. This occurrence shows the greatest variety of crystalline graphite morphologies recognized to date from a single deposit. These morphologies described herein include flakes, cryptocrystalline and spherulitic aggregates, and dish-like forms. Colloform textures, displayed by many of the cryptocrystalline aggregates, are reported here for the first time from any graphite deposit worldwide. Textural relationships indicate that spherulitic aggregates and colloform graphite formed earlier than flaky crystals. This sequence of crystallization is in agreement with the precipitation of graphite from fluids with progressively decreasing supersaturation.

The structural characterization carried out by means of Raman spectroscopy shows that, with the exception of colloform graphite around silicate grains and pyrite within the host rocks, all graphite morphologies display very high crystallinity. The microscale SIMS study reveals light stable carbon isotope ratios for graphite $\left(\delta^{13} \mathrm{C}=-34.5\right.$ to $-30.2 \%$ ), which are compatible with the assimilation of carbon-bearing metapelites in the Borrowdale Volcanic 
Group magmas. Within the main mineralized breccia pipe-like bodies, the isotopic signatures (with cryptocrystalline graphite being lighter than flaky graphite) are consistent with the composition and evolution of the mineralizing fluids inferred from fluid inclusion data which indicate a progressive loss of $\mathrm{CO}_{2}$. Late graphite-chlorite veins contain isotopically heavier spherulitic graphite than flaky graphite. This agrees with $\mathrm{CH}_{4}$-enriched fluids at this stage of the mineralizing event, resulting in the successive precipitation of isotopically heavier graphite morphologies. The isotopic variations of the different graphite morphologies can be attributed therefore to changes in the speciation of carbon in the fluids coupled with concomitant changes in the $\mathrm{XH}_{2} \mathrm{O}$ during precipitation of graphite and associated hydrous minerals (mainly epidote and chlorite).

Key words: Graphite, morphology, Raman, carbon isotopes, Borrowdale

\section{$\underline{\text { Introduction }}$}

The graphite crystal structure consists of a continuous bidimensional array of six-fold rings of carbon atoms stacked along the c-axis. Thus, as for most other minerals with layered structures (e.g. phyllosilicates), the commonest habits of graphite are platy, flaky or scaly crystals (Kwiecinska 1980; Kavanagh and Schlogl 1988; Jaszczak 1995; Luque et al. 1998). However, in spite of its layered structure several other morphologies have been reported both in natural occurrences (rocks and meteorites) and in synthetic compounds (for instance, cast irons). Among these unusual graphite morphologies, the most common is spherulites which may occur in many rock types (Gellatly 1966; Rumble et al. 1982; Duke and Rumble 1986; Katz 1987; Kvasnitsa et al. 1999; Doroshkevich et al. 2007), as a result of precipitation from fluids or melts. In addition, spherulitic graphite has also been found in some chondrites (e.g. Mostefaoui et al. 2000, 2005; El Goresy et al. 2005) and it is a common morphology developed in cast irons (Cooper et al. 2003; Östberg 2006; and references therein).

Fibrous (tubular) graphite has been found in artificially produced carbons (Jaszczak 1995) as well as in some meteorites (Mostefaoui et al. 2005) and igneous rocks (Jaszczak et al. 2007). Finally, other graphite morphologies 
including polyhedral (Gogotsi et al. 2000), columnar, pseudodipyramidal, pseudodipyramidal-prismatic (Kvasnitsa et al. 1999), and cone-shaped (Jaszczak et al. 2003, 2007) have been described.

The goal of the present paper is to describe the unique diversity of graphite morphologies occurring in a single paragenesis from the renowned epigenetic graphite deposit at Borrowdale in the English Lake District (Cumbria, UK; Fig. 1). The geological setting of this graphite deposit is also unusual, because it is one of only two known examples of graphite mineralization hosted by volcanic rocks (Barrenechea et al. 1997; Luque et al. 1998). Morphology of minerals is governed by crystalline structure and the physico-chemical conditions prevailing during nucleation and growth. Similarly, some geochemical features are also dependent upon the conditions of crystal growth. Thus, combining structural and isotopic characterization of the various graphite morphologies could help unravel the evolution of the mineralizing process in the particular environment of the volcanic-hosted deposit at Borrowdale, and more generally provide key information on graphite deposition from fluids.

\section{Geological setting}

The Borrowdale graphite deposit consists of mineralized faults hosted by andesite lavas and sills belonging to the upper Ordovician (Katian) Borrowdale Volcanic Group, and by a probably contemporaneous hypabyssal dioritic intrusion (Millward 2004) (Fig. 1). Previous geological studies of the deposit by Ward (1876) and Strens (1965) stated that narrow veins and stringers filling the faults comprise massive graphite and chlorite along with quartz. The richest deposits are developed at the intersections of the faults where there are steeply inclined pipe-like bodies up to $1 \times 3 \mathrm{~m}$ in cross-section and from a few metres to over $100 \mathrm{~m}$ in length (Ward 1876). The pipe-like bodies contain nodular masses and patches of graphite, typically $1-2 \mathrm{~cm}$ across, but ranging from a few millimetres to $1 \mathrm{~m}$ or more; the yellow-brown matrix comprises intensely altered wall-rock and brecciated quartz.

The volcanic rocks are underlain by the Skiddaw Group, a succession of marine turbiditic mudstones and sandstones, possibly late Cambrian to mid Ordovician in age, and at least $5000 \mathrm{~m}$ thick (Cooper et al. 1995, 2004). Several 
lines of evidence suggest that Skiddaw Group rocks have contributed to the geochemical development of later aspects of Lake District geology. In particular, the presence of garnet phenocrysts in peraluminous rocks in the Borrowdale Volcanic Group and associated intrusions (Fitton 1972) has been attributed to the assimilation of pelitic material, most likely from the Skiddaw Group (McConnell et al. 2002). Sulfur isotope data from sulfides within these volcanic rocks also support this contention (Lowry et al. 1991). Preliminary data on the bulk carbon isotopic composition of carbonaceous matter disseminated within the Skiddaw metapelites are close to $-28.5 \%$ (Barrenechea et al. 2008).

\section{Analytical methods}

\section{Petrographic study}

Samples from the graphite ore body and its host volcanic rocks were studied on polished thin sections with a Zeiss Axiophot microscope using both transmitted and reflected light. The recognition of graphite morphologies was complemented with the study of selected samples by scanning electron microscopy (SEM) on gold-coated fragments using a Jeol JSM6400 microscope operated at $40 \mathrm{kV}$.

\section{Raman spectroscopy}

Raman spectra were collected with a Renishaw INVIA spectrometer at the Ecole Normale Superieure (Paris, France) on the polished thin sections used for the petrographic study. This method allows for measurements in situ and for the preservation of the textural relationships between graphite and the rest of the minerals in the assemblage. All the measurements were done focusing the laser beam beneath the surface of transparent minerals (usually quartz, chlorite, and epidote) associated with graphite to avoid the mechanical disruption of the graphite structure at the surface of the thin section due to polishing (Pasteris 1989; Beyssac et al. 2003). The $514.5 \mathrm{~nm}$ wavelength of a $20 \mathrm{~mW}$ Spectra Physics Argon laser focused through a Leica DMLM microscope with a $100 x$ objective $(N . A .=0.90)$ was used for the analyses. A 
$1800 \mathrm{gr} / \mathrm{mm}$ and a RENCAM CCD detector were used to disperse and analyze the signal.

Under these conditions the spatial resolution is $\sim 1 \mu \mathrm{m}$ and the spectral resolution is close to $1 \mathrm{~cm}^{-1}$. Laser power on the sample surface was reduced to $2 \mathrm{~mW}$ to avoid radiation damage on graphite. Raman analysis of graphite might also be affected by polarization effects between the incident laser electromagnetic field and the structure of graphite. This effect might virtually enhance the defect bands especially for measurement on the graphite edge planes. These effects are rather weak with a $514.5 \mathrm{~nm}$ wavelength (Tan et al. 2004), and to further attenuate them we used a $1 / 4$ wavelength plate before the microscope which yields a circular polarization of the laser.

About twenty spectra of each type of graphite morphology were recorded to gain an insight into the structural heterogeneity within the sample. Acquisition time was 10 seconds and 5 accumulations ensured a good signal to noise ratio. No significant changes were observed in the second order Raman region of graphite, and thus the study focused on the first order Raman spectra (1100 to $2000 \mathrm{~cm}^{-1}$ ). The Raman parameters (peak position, band area, and band intensity) were determined with the computer program PeakFit 3.0 using a Voigt function.

\section{Stable carbon isotope analyses}

Secondary ion mass spectrometry (SIMS) analyses were performed on the Cameca ims 1270 ion microprobe in the N.E.R.C. Scientific Services' Edinburgh Ion Microprobe Facility at the University of Edinburgh. Gold-coated polished thin sections were analyzed using negative secondary ions sputtered with a positively charged $\mathrm{Cs}^{+}$beam. The spot size was $20 \mu \mathrm{m}$. The results were checked using the graphite standard USGS24 $\left(\delta^{13} \mathrm{C}=-16.05 \%\right.$; Coplen et al. 2006). Five measurements were made on the standard at the start and end of each 20 analyses - thus enabling calibration of the sample measurements against 10 standard measurements. Under these conditions, the precision of the point analysis is close to $0.2 \%$. The $\delta^{13} \mathrm{C}$ values are referred to the PDB standard. 


\section{Graphite morphologies}

Graphite in the Borrowdale deposit occurs as subspherical to ellipsoidal aggregates (nodules hereafter) and as irregular patches or small veins within altered volcanic rocks of the Borrowdale Volcanic Group and in an associated hypabyssal dioritic intrusion. Nodules and patches may reach up to $10-15 \mathrm{~cm}$ in diameter or major length. Their typical size is $1-2 \mathrm{~cm}$, though nodules up to $1 \mathrm{~m}$ have been recorded (Ward 1876; Fig. 2a). Graphite also occurs along fault planes in the volcanic rocks, usually associated with chlorite.

Graphite morphologies recognized within the nodules and patches are widely diverse and include both individual forms and aggregates (i.e. groups of individual forms; Table 1). Platy, flaky or scaly graphite crystals (up to $300 \mu \mathrm{m}$ long and $50 \mu \mathrm{m}$ wide) are by far the most abundant $(\approx 90 \%)$, showing no preferred orientation relative to the margins of the nodules. Locally, composite nodules consisting of both flaky and cryptocrystalline graphite have been recognized (Fig. 2b), with flaky graphite usually surrounding cryptocrystalline graphite; the latter may form bands (i.e. colloform textures) around quartz fragments. In some nodules, thin coatings of flaky graphite on quartz fragments (termed hereafter as encapsulated fragments) have been recognized within cryptocrystalline graphite (Fig. 2c). In addition, cryptocrystalline graphite may form rounded patches within flaky graphite (Fig. 2d) and it also occurs with colloform textures, forming bands and globules dispersed within the host rock (Fig. 2e). Colloform graphite in the host rock can be observed around both silicate and pyrite grains (Fig. 2f).

Along with flaky and cryptocrystalline graphite two other morphological types have been recognized: spherulites and ring-like forms. Spherulites consist of radiating arrays of fibrous graphite crystals. In some cases, minute silicate grains can be observed forming the core of the spherulites. In the Borrowdale deposit, spherulites occur in four different settings: 1) as individual forms, 1-5 $\mu \mathrm{m}$ in diameter, or aggregates disseminated within the volcanic rock (Fig. 3a), 2) as individual forms, $5-40 \mu \mathrm{m}$ in diameter, within flaky graphite (Fig. 3b), 3) as individual forms, 1-3 $\mu \mathrm{m}$ in diameter, enclosed in encapsulated quartz fragments (Fig. 2c), and 4) as aggregates, $5-10 \mu \mathrm{m}$ in diameter, associated with chlorite along fault zones (Fig. 3c). Ring-like textures are usually hosted by 
cryptocrystalline graphite (Fig. 2c) or included within encapsulated fragments. Rings are 1-2 $\mu \mathrm{m}$ wide and consist of tiny graphite crystallites arranged parallel to both silicate and sulphide (mainly pyrite) cores.

Finally, "graphic-like" intergrowth textures, consisting of thin curved and tapering graphite flakes within chlorite (Fig. 3d), have been observed in samples from fault zones within the volcanic rock. In places, graphite in graphite-chlorite intergrowths shows a vermicular (i.e. worm-like) morphology (Fig. 3e).

In addition to these morphologies, the SEM study revealed the presence of concave disks (dish-shaped aggregates) of graphite (up to $40 \mu \mathrm{m}$ in diameter) showing rough surfaces (Fig. 3f).

\section{$\underline{\text { Raman data }}$}

The Raman spectra of graphite are sensitive to the changes in the degree of crystal perfection ("crystallinity") along the basal plane of the graphite structure (Wopenka and Pasteris 1993) that can be correlated to the in-plane crystallite size $\left(L_{a}\right)$. Thus, the first order Raman spectra of highly crystalline graphite displays a sharp peak at $\approx 1580 \mathrm{~cm}^{-1}$ (ordered or $G$ band). Two additional bands at $\approx 1350 \mathrm{~cm}^{-1}$ and $1620 \mathrm{~cm}^{-1}$ (D1 and D2 bands) are recorded in the first order Raman spectra of poorly crystalline graphite, the D2 band occurring as a shoulder on the $G$ band. The intensity and area ratios for the disorder to order bands decrease with increasing crystallinity (Wopenka and Pasteris 1993; Beyssac et al. 2003). The most prominent feature in the secondorder Raman spectra of well ordered graphite is a peak close to $2700 \mathrm{~cm}^{-1}$ (S1 band) which splits into two bands. Recent detailed reviews of the physics behind the Raman spectrum of graphite are provided by Reich and Thomsen (2004) and Pimenta et al. (2007).

All graphite morphologies from the Borrowdale deposit correspond to structurally well ordered graphite according to the Raman data. The intensity and area ratios for the $D$ and $G$ bands in the first-order spectra are consistent with highly crystalline graphite. In addition, no significant changes were observed in the second order Raman region, all the spectra showing welldefined shoulders at $\approx 2685 \mathrm{~cm}^{-1}$ on the S1-peak, which is indicative of the attainment of tri-periodic order in the structure (Lespade et al. 1982). 


\section{Flaky graphite}

Raman spectra of flaky graphite from Borrowdale display a sharp $G$ band and weak or absent D1 and D2 disorder bands (Fig. 4a). The intensity and area ratios for the disorder to order bands $(R 1=D 1 / G$ peak intensity ratio, and $R 2=$ $\mathrm{D} 1 /(\mathrm{G}+\mathrm{D} 1+\mathrm{D} 2)$ peak area ratio; Beyssac et al. 2002) average 0.04 for R1, and 0.06 for R2 (Table 2). These features of the Raman spectra indicate a high degree of crystalline perfection along the basal plane of the graphite structure. The average crystallite size $L_{a}$ is in excess of $2000 \AA$ according to the estimation of Wopenka and Pasteris (1993) which is based on the area ratio of the $D 1$ to $G$ bands.

\section{Cryptocrystalline graphite}

Significant differences were observed in the first-order Raman spectra of cryptocrystalline graphite occurring in composite nodules in the pipe-like bodies compared with that found as colloform bands around silicate or sulphide grains within the volcanic host rocks (Table 2).

a) Cryptocrystalline graphite in composite nodules displays the Raman features of highly ordered graphite, that is, small or absent D1 peak and sharp $\mathrm{G}$ band (Fig. 4b). The average values for R1 and R2 are 0.09 and 0.05 , respectively. Such values agree with in-plane crystallite sizes larger than $2000 \AA$.

b) Colloform graphite around silicate grains in the volcanic host rock shows Raman spectra corresponding to graphite of lower crystallinity (Fig. 4c). In particular, the parameters of the first-order spectra R1 and R2 have higher average values ( 0.23 and 0.25 , respectively) than those calculated for the other morphologies. Such values agree with $\mathrm{L}_{\mathrm{a}}$ crystallite sizes of 200 to $300 \AA$.

c) Finally, the Raman spectra of colloform graphite around pyrite grains in the host rock (Fig. 4d) show the highest $\mathrm{R} 1$ and $\mathrm{R} 2$ average values ( 0.26 and 0.28 , respectively) and hence the lowest degree of crystallinity $\left(L_{a}=150-300 \AA\right)$. 


\section{Spherulitic graphite}

The recorded Raman spectra of spherulitic graphite from the Borrowdale deposit also correspond to highly crystalline graphite (Fig. 4e). No differences have been found for spherulites disseminated in the host rocks or within encapsulated quartz fragments. The parameters of the first-order spectra R1 and R2 have average values of 0.07 and 0.06 , respectively. Such values agree with average crystallite sizes larger than $2000 \AA$. Graphite spherulites within flaky graphite were not analysed because they can only be recognized at the surface of the polished thin sections.

\section{Graphite in chlorite}

Graphite (both flaky and vermicular) in "graphic"-like intergrowths and graphite spherulites within chlorite shows Raman spectra corresponding to wellordered graphite (Fig. 4f). However, R1 and R2 values are slightly higher than those for flaky and cryptocrystalline graphite within the nodules, and also compared to spherulitic graphite disseminated in the host rock or enclosed in encapsulated quartz fragments. The parameters of the first-order spectra R1 and R2 have average values of 0.11 and 0.16 , respectively. Such values correspond to $L_{a}$ crystallite sizes in the range between 1000 and $1500 \AA$.

\section{Stable carbon isotope data}

The stable carbon isotope ratios for the different morphologies analysed are given in Table 3. No data were obtained for some of the morphologies because they were smaller than the spot size of the ion microprobe. It is worth noting that the analyses of each morphological type fall within very narrow ranges. The most abundant morphology within nodules and disseminations (flakes) has one of the heaviest isotopic signatures (average $\delta^{13} \mathrm{C}_{\mathrm{PDB}}=-30.26$ $\%$ ) for the graphite in the deposit. Such values are close to those found in graphite spherulites within chlorite (average $\delta^{13} \mathrm{C}_{\mathrm{PDB}}=-30.15 \%$ ). By contrast, cryptocrystalline graphite in composite nodules has significantly lighter isotopic signatures (average $\delta^{13} \mathrm{C}_{\mathrm{PDB}}=-33.70 \%$ ) with no apparent zoning across the 
banded texture (Fig. 5). The lightest carbon isotope ratios correspond to vermicular graphite within chlorite (average $\delta^{13} \mathrm{C}_{\mathrm{PDB}}=-34.49 \%$ ).

\section{Discussion}

\section{Origin of graphite morphologies}

The variation in the morphology of minerals is related to factors influencing the growth forms. The theoretical morphology of a mineral, inferred from its structure, can be used as a reference to evaluate the influence of the different factors that affect its morphology in a certain setting. In the case of graphite, the structure is defined by layers of carbon atoms arranged parallel to the (0001) plane in a hexagonal crystalline lattice, $A B A B$ stacking of aromatic planes (a rhomboedral polytype, $A B C A B C$ stacking, exists as well but is very minor). Within these layers, strong covalent bonds exist. However, weak van der Waals forces keep the carbon layers together. The characteristics of this structure determine that (0001) surface exclusively cuts weak bonds. Therefore, this is a low attachment energy surface. By contrast, surfaces in the c-axis zone cut strong bonds and consequently have much higher attachment energies. It is well known that a direct relationship exists between the attachment energy of a surface and its growth rate, since the higher the attachment energy the faster the growth units attach onto it. Thus, any surface in the c-axis zone will grow much faster than the (0001) surface. Therefore, the expected habit for graphite crystals will be dominated by (0001) faces, whereas faces in the c-axis zone will have a very limited development, with the crystals showing a platy morphology.

Factors that can affect crystal growth must be considered in the interpretation of those graphite crystals showing morphologies that differ significantly from the theoretically expected one. The variation of graphite morphology can be attributed to (1) changes in the carbonaceous precursor, (2) the effect of elements other than carbon present in the environment, and (3) changes in the carbon content of the fluid. Thus, Mostefaoui et al. (2005) ascribed the various morphologies found in chondrites to different carbonaceous precursors. Such an assumption could be applied essentially to graphite in metamorphic rocks formed by graphitization of carbonaceous 
precursors in situ. However, graphite in metamorphic rocks occurs exclusively as flakes. On the other hand, it has been reported that in synthetic systems (i.e. cast irons) some elements (especially magnesium) promote the development of spherulitic graphite (Double and Hellawell 1995; Östberg 2006). This influence can be disregarded in natural (geological) systems because the usual concentrations of such elements in most rocks would lead spherulitic graphite to be the most common morphology, and this does not actually occur. Thus, for fluid-deposited graphite occurrences, changes in the carbon content of the fluid (supersaturation) appear to be the most likely factor controlling the different graphite morphologies. In particular, unusually high supersaturation is required for graphite to be precipitated from moderate-temperature fluids (Pasteris 1999), such as those responsible for the Borrowdale mineralization (Luque et al. 2009). High carbon concentrations also seem to play a key role in the development of graphite spherulites in carbonatite rocks. Spherulitic graphite in carbonatites, however, does not precipitate from a C-O-H fluid, but it crystallizes directly from the carbon-rich magma (Doroshkevich et al. 2007).

According to classical nucleation theory (Walton 1969), the number of critical nuclei that form in a system per unit time is an exponential function of the square of supersaturation. This explains why a large number of crystals reach a small size when nucleation occurs under high supersaturation conditions, while few large crystals are the result of nucleation under low supersaturation (Sunagawa 1987, 2005). Moreover, the formation of aggregates is also characteristic of crystallization from highly supersaturated fluids. The decrease in supersaturation during growth results in an evolution from cryptocrystalline and spherulitic aggregates to polyhedral crystals. If heterogeneous nucleation is considered and it occurs freely over any surface, various textures of polycrystalline aggregates will appear through geometrical selection. Spherulites will be formed on minute, nearly spherical grains during the early stages of nucleation, whereas cryptocrystalline aggregates displaying banding parallel to the substrate surface will nucleate and grow over uneven substrate surfaces (colloform aggregates). Lower supersaturation favours the formation of polyhedral morphologies mainly by spiral growth (Fig. 6).

At high supersaturation conditions the solid-fluid interface becomes rough and crystal growth occurs by an adhesive or continuous mechanism. 
Under these conditions, growth is controlled by volume diffusion (Sunagawa 1987) and the resulting morphologies are much more elongated than those expected at lower supersaturation. If such elongate crystals grow radially around a minute nucleus, a spherulitic aggregate of acicular crystals will appear. In natural spherical graphite it has been shown that these spheres consist of an internal radial arrangement and a thin surface shell with concentric texture (see Jaszczak 1995). Such textures have been interpreted as the result of a cone-helix growth mechanism from a common centre (Double and Hellawell 1974), which is the likely explanation of the origin of graphite spherulites in the Borrowdale deposit. In other cases, for example in marbles from Pargas (Finland), the surfaces of these spheres show outlines of individual graphite crystals with their basal planes lying parallel to the surface. These spheres are very similar to those found disseminated in the volcanic rocks of the Borrowdale deposit (compare figures 3a of this paper and 6-11 in Jaszczak 1995). This arrangement of the basal planes of graphite parallel to the substrate surface could also be responsible for the development of the ring-like textures observed (Fig. 2c).

Dish-like morphologies detected by SEM (Fig. 3f) are reported for the first time in this paper and they can be interpreted on the basis of structural considerations. As explained above, the (0001) surface is a low attachment energy surface while surfaces in the c-axis zone have higher attachment energies. Consequently, the growth units approaching faces in the c-axis zone attach onto them much more rapidly than onto (0001) face. Those faces that grow faster tend to disappear along the growth process. Moreover, when differences between the growth rates of faces in the same zone are at a minimum, curved surfaces or edges will develop. In addition, there is also a relationship between the surface energy of a face and its growth mechanism. Faces with high attachment energy values tend to be rough and grow by an adhesive or continuous mechanism. For dish-like graphite morphologies in the Borrowdale deposit, (0001) faces may have grown by two-dimensional nucleation, as they appear relatively flat and well developed, whereas those faces in the c-axis zone must have grown by a continuous mechanism, appearing as curved ledges (Fig. 3f). 
Colloform aggregates of graphite were developed over irregular substrate surfaces starting from minute crystals of random orientation. After one layer is completed by intermittent growth, repetition of the process will develop the colloform texture. The interruption and resumption of growth inevitably occur in a system where there is an imbalance between the diffusion rate and the growth rate and a critical value such as the energy barrier is involved (Sunagawa 2005). During the early stage of growth, the particle size is small and there is a high density of nuclei resulting in cryptocrystalline aggregates displaying banded textures (colloform) parallel to the substrate surface (Figs. 2c and 5).

Finally, the most common morphology of graphite crystals (i.e. flaky) from the Borrowdale deposit would be developed under lower supersaturation conditions by spiral growth (Fig. 6). Each layer of the graphite structure can be considered as a two-dimensional sheet to which atoms can be added more easily in the in-plane directions than along the stacking direction, that is, the caxis (normal to the layers). So, as expected from its structure, flakes will be the dominant morphology for graphite crystals in any natural system (both in metamorphic and fluid-deposited occurrences; Luque et al. 1998), and any other morphology would result from particular conditions during nucleation and growth. Textural relationships in the composite nodules from the Borrowdale deposit support the conclusion that flaky graphite crystallized later than those morphologies that formed under high supersaturation conditions (cryptocrystalline or spherulitic graphite; Figs. 2b, 2d, and 3b).

\section{Structural features of graphite morphologies}

According to Raman data, graphite from the Borrowdale deposit is mainly well-ordered. This is an unexpected feature considering that it was formed at relatively low temperature $\left(\sim 500^{\circ} \mathrm{C}\right.$; Luque et al. 2009). Under the same analytical conditions, metamorphic graphite formed at equivalent temperatures (i.e. greenschist to epidote-amphibolite facies) distinctively shows a lower degree of order (R1 ratio ranging from 0.30 to 0.50 , and average $\mathrm{R} 2$ close to 0.45; Beyssac et al. 2002) than that estimated in this study of the Borrowdale deposit. Compared with metamorphic graphite, the R1 and R2 ratios of the Raman spectra for the Borrowdale graphite (except for colloform graphite 
surrounding silicate or sulphide grains in the volcanic host rock) are in the range for graphite occurring at high grade metamorphic conditions, from upper amphibolite to granulite facies rocks (Pasteris and Wopenka 1991; Wopenka and Pasteris 1993; Beyssac et al. 2002). Thus, the Borrowdale deposit represents the first example of fully ordered graphite in a large graphite occurrence precipitated from fluids at moderate temperature. The reasons for such an anomalous crystallinity are discussed in detail in a previous paper (Luque et al. 2009) and can be summarized as: (1) the different mechanism of formation for fluid-deposited graphite compared with metamorphic graphite, the latter being the progressive transformation in situ of a carbonaceous precursor, (2) the stability field for fully ordered graphite+fluid in the $\mathrm{C}-\mathrm{O}-\mathrm{H}$ system is larger than that for poorly ordered graphite even at relatively low temperatures, (3) the heterogeneous nucleation mechanism operating during graphite deposition that reduced the energy barrier for graphite precipitation from the fluid, and (4) the fluids responsible for the Borrowdale mineralization had the very high initial concentration of carbon required for the precipitation of graphite from such moderate temperature fluids.

Considering the overall high crystallinity of graphite in the deposit, an explanation of the lower crystallinity displayed by the cryptocrystalline graphite in the colloform textures around pyrite and silicate grains within the volcanic host rock is required. Colloform graphite around pyrite shows the lowest crystallinity, with average in-plane crystallite sizes ranging from 150 to $300 \AA$. The catalytic effect of certain compounds on the precipitation of graphite, particularly sulphides (pyrrhotite, stibnite), is well known (Jedwab and Boulegue 1984; Duke and Rumble 1986). Silicates also have been proposed as catalytic agents during the graphitization of carbonaceous matter through metamorphism (Grew 1974). So, it is likely that the increased rate of graphite precipitation caused by these catalysts induced some kind of disorder in the graphite structure. However, it is worth noting that colloform graphite around quartz in composite nodules within the mineralized bodies and colloform graphite around silicates in the volcanic host rocks have contrasting crystallinities. Colloform graphite around quartz has $L_{a}$ values in excess of $2000 \AA$, whilst colloform graphite around silicates in the volcanic host rocks has $L_{a}=200-300 \AA$. Thus, it seems likely that ferromagnesian minerals within the host rock caused a similar 
effect to that of pyrite, whereas quartz does not appear to influence any structural disorder in the precipitated graphite.

As with cryptocrystalline graphite, graphite spherulites also developed under high supersaturation conditions. Raman parameters measured on spherulitic graphite within nodules from the mineralized bodies indicate a high degree of ordering, similar to that found in graphite from high-grade metamorphic rocks, with $L_{a}$ larger than of $2000 \AA$. In addition, graphite spherulites in the chlorite-graphite veins also have large $L_{a}$ crystallite sizes (>1000 A). Previous Raman data on graphite spherulites both in synthetic systems (cast irons) and natural occurrences (chondrite meteorites and carbonatites) point to poorly crystalline materials. Cooper et al. (2003) reported Raman spectra from spherulitic graphite in cast irons showing intense D1 and D2 peaks that reveal low crystallinity. Mostefaoui et al. (2000) found spherulitic graphite in primitive chondrites with $L_{a}$ between 30 and $40 \AA$. Similarly, Doroshkevich et al. (2007) reported graphite spherulites in carbonatites with R1 in the range $0.35-0.84$. The large difference in crystallinity between graphite spherulites in cast irons and carbonatites, and those found in Borrowdale can be interpreted as a consequence resulting from an unlikely analytical procedure. In both the cast irons and carbonatites, the Raman measurements were done on polished surfaces and the polishing process appears to be the cause of such a low crystallinity. The Raman spectra on graphite spherulites in chondrites were obtained over unpolished surfaces, so a different argument should be invoked to explain its low crystallinity. Graphite in chondrites results from heating of carbonaceous precursors at high temperatures $\left(>1000^{\circ} \mathrm{C}\right)$ for a very short period of time, with no pressure contribution (Mostefaoui et al. 2000). Such conditions are similar to those of experimental graphitization (BenyBassez and Rouzaud 1985) in which the products displayed Raman spectra corresponding to poorly crystalline graphite. Thus, the very different crystallinity of graphite spherulites in chondrites compared with those from Borrowdale should be attributed to their contrasting mechanisms of formation. 


\section{Significance of the carbon isotope ratios}

In a first approach, stable carbon isotope ratios in graphite provide information about the origin of the carbon. For fluid-deposited graphite, the possible sources of carbon are (a) devolatilization of carbonaceous metapelites, (b) decarbonation of carbonate rocks, and (c) mantle-derived carbon (Luque et al. 1998). Each source has carbon isotope ratios falling within characteristic ranges. The total range of $\delta^{13} \mathrm{C}$ values for organic matter (both living and dead) is from about -40 to $+6 \%$, with an average $\delta^{13} \mathrm{C}$ value of $-25 \%$; that is, organic materials are isotopically light (Weis et al. 1981). Marine carbonates of Cambrian to Tertiary age, on the other hand, have heavier $\delta^{13} \mathrm{C}$ values which lie within \pm 2 units of $0 \%$. The isotopic compositions of diamonds and mid-oceanic ridge basalts (MORB) indicate that carbon from the mantle is significantly heavier $\left(\delta^{13} \mathrm{C}=-7 \%\right.$ ) than biogenically derived carbon (Crespo et al. 2006).

The interpretation of the carbon isotopic signature in terms of the carbon source is complicated by fractionation effects related to the thermal history of the rock or to carbon-exchange between graphite and other carbon-bearing species, such as an isotopically heavier carbonate (which in turn is also governed by temperature). In the fractionation that occurs between two phases, the more oxidized species of the pair becomes relatively enriched in the heavier isotope, i.e. ${ }^{13} \mathrm{C}$. In the maturation of organic matter, fractionation occurs between organic residues and their evolved gas species. For a fluid co-existing with the FQM buffer, the fluid becomes richer in the oxidized species $\left(\mathrm{CO}_{2}\right)$ with increasing temperature (Frost 1979). Thus, at low temperature and under low $\mathrm{fO}_{2}$ conditions, co-existing $\mathrm{CH}_{4}$ becomes depleted in ${ }^{13} \mathrm{C}$, giving the gas an isotopically lighter signature and the residual carbonaceous matter a heavier one (Bottinga 1969). At relatively high $\mathrm{fO}_{2}$ the carbon-bearing species resulting from devolatilization of carbonaceous matter would be an isotopically light $\mathrm{CO}_{2}$, but heavier than the residual carbonaceous matter. The decarbonation reactions of carbonate minerals result in a ${ }^{13} \mathrm{C}$-enriched $\mathrm{CO}_{2}$ phase. Incorporation of such $\mathrm{CO}_{2}$ into aqueous fluids would lead to the precipitation of isotopically heavy graphite. Finally, the possibility of mixing between different carbon reservoirs before or while graphite precipitated from the fluid should be 
also considered when interpreting the carbon isotopic signature of fluiddeposited graphite (see Luque et al. 1998).

The light isotopic signatures of the different morphologies of graphite from the Borrowdale deposit suggest that the carbon was derived from a biogenic source. This is in good agreement with the geological and geochemical evidence of assimilation of Skiddaw Group metapelites by the volcanic host rocks, and with the presence of zones within the metapelites that have been depleted in carbon and other elements during hydrothermal alteration (e.g. the Crummock Water zone, Fig. 1; Cooper et al. 1988). As previously mentioned, the bulk carbon isotopic analyses of Skiddaw metapelites yielded values close to $\delta^{13} \mathrm{C}=-28.5 \%$. Considering the solidus temperature of andesite magmas, the assimilation of the Skiddaw metapelites should occur at temperatures close to $1100{ }^{\circ} \mathrm{C}$. At such temperature the released carbon species is $\mathrm{CO}_{2}$, and the fractionation factor $\mathrm{C}-\mathrm{CO}_{2}$ is about $5.5 \%$ (Scheele and Hoefs 1992). Thus, the $\delta^{13} \mathrm{C}$ value for the $\mathrm{CO}_{2}$ at the assimilation temperature was close to $-23 \%$. At the temperature estimated for graphite precipitation $\left(480-500{ }^{\circ} \mathrm{C}\right.$; Luque et al. 2008), the fractionation factors for $\mathrm{CO}_{2}-\mathrm{C}$ would be close to $10.5 \%$ (Bottinga 1969). This means that the graphite precipitated from this $\mathrm{CO}_{2}$-rich fluid should have an isotopic signature close to $-33.5 \%$.

Fluid inclusion data in the Borrowdale deposit (Ortega et al. 2008, Luque et al. 2008) have shown that fluids involved in the mineralizing process had average compositions of 0.65 mol fraction $\mathrm{H}_{2} \mathrm{O}$ and $\mathrm{XCO}_{2} /\left(\mathrm{XCO}_{2}+\mathrm{XCH}_{4}\right)=0.69$ in the main stage of graphite precipitation. Later, the fluids evolved towards 0.93 mol fraction $\mathrm{H}_{2} \mathrm{O}$ and $\mathrm{XCO}_{2} /\left(\mathrm{XCO}_{2}+\mathrm{XCH}_{4}\right)=0$, with $\mathrm{CH}_{4}$ being the only carbonic species in the fluid in the final stages of fluid circulation. The graphitemineralizing fluid would be a vapour-like supercritical phase at the beginning of the graphite precipitation, evolving to a liquid-rich fluid as the deposition proceeded. The conspicuous relationship between epidote and graphite in the breccia pipe-like bodies strongly suggests that the graphite precipitation started following the reaction $\mathrm{CO}_{2} \rightarrow \mathrm{C}+\mathrm{O}_{2}$. Since the average $\mathrm{XCO}_{2}$ in the early fluid is 0.24 and epidote is not stable for $\mathrm{XCO}_{2}>0.2$ (Liou 1993), epidote crystallization was likely triggered by the consumption of $\mathrm{CO}_{2}$ in the reaction of graphite precipitation. The earlier morphologies (colloform) crystallizing in the pipe-like bodies display lighter signatures $\left(\delta^{13} \mathrm{C}=-33.7 \%\right.$ ) than flaky graphite 
$\left(\delta^{13} \mathrm{C}=-30.2 \%\right)$ that formed somewhat later. The values for cryptocrystalline graphite forming colloform textures in the composite nodules has therefore isotopic signatures similar to that of graphite crystallizing from $\mathrm{CO}_{2}$ in the fluid with an initial $\delta^{13} \mathrm{C}$ around $-23 \%$. Flaky graphite is on average $3.5 \%$ heavier than colloform graphite within the main mineralized bodies, and this can be ascribed to $\mathrm{CO}_{2}$ consumption in the fluid. It has been documented that changes in the $\mathrm{CO}_{2} / \mathrm{CH}_{4}$ ratio in the fluid may result in relatively large isotopic shifts. Such variations in the $\mathrm{CO}_{2} / \mathrm{CH}_{4}$ ratio can be also influenced by changes in the $\mathrm{XH}_{2} \mathrm{O}$, for example, by hydration reactions occurring simultaneously with graphite deposition (Duke and Rumble 1986).

Fluid inclusion data reveal a progressive enrichment in water as graphite mineralization proceeded, pointing to the involvement of water-generating reactions during graphite deposition: (1) $\mathrm{CH}_{4}+\mathrm{O}_{2} \rightarrow \mathrm{C}+2 \mathrm{H}_{2} \mathrm{O}$ or (2) $\mathrm{CH}_{4}+$ $\mathrm{CO}_{2} \rightarrow 2 \mathrm{C}+2 \mathrm{H}_{2} \mathrm{O}$ (or both). The reaction between $\mathrm{CH}_{4}$ and $\mathrm{CO}_{2}$ to form graphite is kinetically very sluggish, so reaction (1) seems to be more likely to account for graphite deposition in a later stage of the mineralizing event. The simultaneous consumption of $\mathrm{CH}_{4}$ and water enrichment in the fluid drove its composition along the graphite saturation curve towards the $\mathrm{CO}_{2}$-rich side, resulting in an isotopic shift towards lighter $\delta^{13} \mathrm{C}$ values in the precipitated graphite (Fig. 7). In this way, the isotopic signature of vermicular graphite $\left(\delta^{13} \mathrm{C}\right.$ $=-34.5 \%$ ) in graphite-chlorite assemblages from fault-fills would be lighter than that of the earlier formed spherulitic graphite $\left(\delta^{13} \mathrm{C}=-30.2 \%\right)$. This suggests, though does not prove, that graphite-chlorite veins represent a slightly later mineralizing phase involving deposition from fluids in which the dominant carbonic species became $\mathrm{CH}_{4}$. The variations in the $\delta^{13} \mathrm{C}$ values between the different graphite morphologies (both in the pipes and in the graphite-chlorite veins) can be explained therefore through a Rayleigh distillation mechanism from an initial $\mathrm{CO}_{2}-\mathrm{CH}_{4}-\mathrm{H}_{2} \mathrm{O}$ single fluid promoting graphite precipitation over a narrow (nearly isothermal) temperature interval. This interpretation is consistent with the evolution of the composition of the fluid obtained from fluid inclusion data and agrees with the morphology of the mineralized bodies (pipe-like breccias) which indicates a rapid, catastrophic mineralizing event. 


\section{Conclusions}

Graphite in the Borrowdale (Cumbria, UK) deposit occurs as large masses within mineralized pipe-like bodies, as late graphite-chlorite veins, and disseminated through its andesite and dioritic host rocks. Graphite from Borrowdale shows the greatest variety of crystalline morphologies recognized up to now from a single deposit. In addition to flaky crystals, graphite also occurs as cryptocrystalline aggregates displaying colloform textures (reported for the first time in any graphite deposit worldwide), as spherulitic aggregates, and with dish-like morphologies. Colloform graphite occurs around silicate (both ferromagnesian minerals of the volcanic host rock and quartz within the breccia pipe mineralized body) and sulphide (mainly pyrite in the host rock) substrates. Textural relationships indicate that spherulitic aggregates and colloform textures are earlier than flaky crystals. This sequence of crystallization is related to the precipitation of graphite from fluids with progressively decreasing supersaturation.

With the exception of colloform graphite around silicate and pyrite grains within the host rocks, all graphite morphologies display very high crystallinity, as revealed by their in-plane crystallite sizes. Such high crystallinity is unusual for moderate-temperature fluid-deposited graphite and this has been discussed in detail in a previous paper (Luque et al. 2009). The lower crystallinity of colloform graphite within the host rock is attributed to the structural disorder induced by the catalytic effect of ferromagnesian and sulfide minerals during crystallization.

The light stable carbon isotope ratios of graphite $\left(\delta^{13} \mathrm{C}=-34.5\right.$ to $-30.2 \%$ ) are compatible with the assimilation of carbon-bearing metapelites in the Borrowdale Volcanic Group magmas. In the main mineralized breccia pipe-like bodies, the microscale isotopic signatures (with cryptocrystalline graphite being lighter than flaky graphite) are consistent with the composition and evolution of the mineralizing fluids which indicate a progressive loss of $\mathrm{CO}_{2}$ (from precipitation of graphite through the reaction $\mathrm{CO}_{2} \rightarrow \mathrm{C}+\mathrm{O}_{2}$ ). Late graphitechlorite veins contain isotopically heavier spherulitic graphite than flaky graphite. This agrees with the fact that the fluids, as evidenced from fluid inclusion data, were richer in $\mathrm{CH}_{4}$ at this stage of the mineralizing event, resulting in the successive precipitation of isotopically heavier graphite 
morphologies. The dominant graphite-producing reaction at this stage was $\mathrm{CH}_{4}$ $+\mathrm{O}_{2} \rightarrow \mathrm{C}+2 \mathrm{H}_{2} \mathrm{O}$. Thus, the isotopic variations of the different graphite morphologies can be attributed to changes in the speciation of carbon in the fluids coupled with concomitant changes in the $\mathrm{XH}_{2} \mathrm{O}$ during precipitation of graphite and associated hydrous minerals (mainly epidote and chlorite).

\section{Acknowledgements}

Access to the Edinburgh Ion Microprobe Facility through N.E.R.C. Scientific Services is gratefully acknowledged. We thank John Craven for his expertise, interest and support. Dr L. Fernández-Díaz is also thanked for helpful suggestions about the mechanisms of nucleation and growth. Technical assistance by E. Baldonedo (Centro de Microscopía Electrónica Luis Bru, UCM) during SEM work is also gratefully acknowledged. This paper is a contribution from project CGL2006-00835 of the Spanish Ministry of Science and Innovation. David Millward publishes with the permission of the Executive Director, British Geological Survey (N.E.R.C.). This study was partly funded by INSU DyETI and ANR JC (GeoCarbons project) to Olivier Beyssac.

\section{$\underline{\text { References }}$}

Barrenechea JF, Luque FJ, Rodas M, Pasteris JD (1997) Vein-type graphite mineralization in the Jurassic volcanic rocks of the external zone of the Betic Cordillera (Southern Spain). Can Mineral 35: 1379-1390

Barrenechea JF, Luque, FJ, Ortega L, Rodas M, Millward D, Beyssac O (2008) Graphite morphologies in the volcanic-hosted deposit at Borrowdale (NW England, UK): preliminary Raman and SIMS data. Macla 9: 91-92

Beny-Bassez C, Rouzaud J-N (1985) Characterization of carbonaceous materials by correlated electron optical microscopy and Raman microspectroscopy. Scanning Electron Microscop 1985: 119-132

Beyssac O, Goffé B, Chopin C, Rouzaud, J-N (2002) Raman spectra of carbonaceous materials in metasediments: a new geothermometer. $J$ metamorphic Geol 20: 859-871 
Beyssac O, Goffé B, Petitet JP, Froigneux E, Moreau M, Rouzaud, J-N (2003)

On the characterization of disordered and heterogeneous carbonaceous materials by Raman spectroscopy. Spectrochim Acta, Part A 59: 22672276

Bottinga $Y$ (1969) Calculated fractionation factors for carbon and hydrogen isotope exchange in the system calcite-carbon dioxide-graphitemethane-hydrogen-water vapor. Geochim Cosmochim Acta 33: 49-64

Cooper AH, Rushton AWA, Molyneux SG, Hughes, RA, Moore RM, Webb BC (1995) The stratigraphy, correlation, provenance and paleogeography of the Skiddaw Group (Ordovician) in the English Lake District. Geol Mag 132: $185-211$

Cooper AH, Fortey NJ, Hughes RA, Molyneux, SG, Moore RM, Rushton, AWA, Stone P, Allen PM, Cooper DC, Evans JA, Hirons SR, Webb, BC (2004) The Skiddaw Group of the English Lake District. Memoir of the British Geological Survey. London: HMSO

Cooper CA, Elliot R, Young RJ (2003) Investigation of the graphitic microstructure in flake and spheroidal cast irons using Raman spectroscopy. J Mater Sci 38: 795-802

Cooper D C, Lee MK, Fortey NJ, Cooper AH, Rundle CC, Webb BC, Allen PM (1988) The Crummock Water aureole: a zone of metasomatism and source of ore metals in the English Lake District. J Geol Soc, London 145: $523-540$

Coplen TB, Brand WA, Gehre M, Gröning M, Meijer HAJ, Toman B, Verkouteren RM (2006) New guidelines for $\delta^{13} \mathrm{C}$ measurements. Anal Chem 78: 2439-2441

Crespo E, Luque J, Rodas M, Wada H, Gervilla F (2006) Graphite-sulfide deposits in Ronda and Beni Bousera peridotites (Spain and Morocco) and the origin of carbon in mantle-derived rocks. Gondwana Res 9, 279290

Doroshkevich AG, Wall F, Ripp, GS (2007) Magmatic graphite in dolomite carbonatite at Pogranichnoe, North Transbaikalia, Russia. Contrib Mineral Petrol 153: 339-353 
Double DD, Hellawell A (1974) Cone-helix growth forms of graphite. Acta Metall 22: $481-487$

Double DD, Hellawell A (1995) The nucleation and growth of graphite: the modification of cast iron. Acta Metall Mater 43: 2435-2442

Duke EF, Rumble D (1986) Textural and isotopic variations in graphite from plutonic rocks, South-Central New Hampshire. Contrib Mineral Petrol 93: 409-419

El Goresy A, Zinner E, Pellas P, Caillet C (2005) A menagerie of graphite morphologies in the Acapulco meteorite with diverse carbon and nitrogen isotopic signatures: Implications for the evolution history of acapulcoite meteorites. Geochim Cosmochim Acta 69: 4535-4556

Fitton JG (1972) The genetic significance of almandine-pyrope phenocrysts in the calc-alkaline Borrowdale Volcanic Group, northern England. Contrib Mineral Petrol 36: 231-248

Frost BR (1979) Mineral equilibria involving mixed-volatiles in a C-O-H fluid phase: the stabilities of graphite and siderite. Am J Sci 279: 1033-1059

Gellatly DC (1966) Graphite in natural and experimental carbonate systems. Miner Mag 35: 963-970

Gogotsi Y, Libera JA, Kalashnikov N, Yoshimura M (2000) Graphite polyhedral crystals. Science 290: 317-320

Grew ES (1974) Carbonaceous materials in some metamorphic rocks of New England and other areas. J Geol 82: 50-73

Jaszczak JA (1995) Graphite: Flat, Fibrous and Spherical. In Mendenhall GD (ed) Mesomolecules: From Molecules to Materials. Chapman and Hall, London

Jaszczak JA, Robinson GW, Dimovski S, Gogotsi Y (2003) Naturally occurring graphite cones. Carbon 41: 2085-2092

Jaszczak JA, Dimovski S, Hackney SA, Robinson, GW, Bosio P, Gogotsi Y (2007) Micro- and nanoscale graphite cones and tubes from Hackman Valley, Kola Peninsula, Russia. Can Mineral 45: 379-389

Jedwab J, Boulegue J (1984) Graphite crystals in hydrothermal vents. Nature, 310: $41-43$

Katz MB (1987) Graphite deposits of Sri Lanka: a consequence of granulite facies metamorphism. Miner Deposita, 22, 18-25 
Kavanagh A, Schlogl R (1988) The morphology of some natural and synthetic graphites. Carbon 26: 23-32

Kvasnitsa VN, Yatsenko VG, Jaszczak JA (1999) Disclinations in unusual graphite crystals from anorthosites of Ukraine. Can Mineral 37: 951-960

Kwiecinska B (1980) Mineralogy of natural graphites. Polska Akad Nauk, Prace Mineral, 67: 5-79

Lespade P, Al-Jishi R, Dresselhaus, MS (1982) Model for Raman scattering from incompletely graphitized carbons. Carbon 20: 427-431

Liou JG (1993) Stabilities of natural epidotes In Hock V and Koller F (eds) Proc 125 Jahre Kappenwand Symposium: 7-16

Lowry D, Boyce AJ, Pattrick RAD, Fallick AE, Stanley CJ (1991) A sulphur isotopic investigation of the potential sulphur sources for Lower Palaeozoic-hosted vein mineralization in the English Lake District. J Geol Soc, London 148, 993-1004

Luque FJ, Pasteris JD, Wopenka B, Rodas M, Barrenechea JF (1998) Natural fluid-deposited graphite: mineralogical characteristics and mechanisms of formation. Am J Sci 298: 471-498

Luque FJ, Ortega L, Barrenechea JF, Millward D, Beyssac O, Huizenga, J-M (2009) Deposition of highly crystalline graphite from moderatetemperature fluids. Geology: in press

McConnell BJ, Menuge JF, Hertogen J (2002) Andesite petrogenesis in the Ordovician Borrowdale Volcanic Group of the English Lake District by fractionation, assimilation and mixing. J Geol Soc, London 159: 417-424

Millward D (2004) The Caradoc volcanoes of the English Lake District. Proc Yorkshire Geol Soc 55: 73-105

Mostefaoui S, Perron C, Zinner E, Sagon, G (2000) Metal-associated carbon in primitive chondrites: Structure, isotopic composition, and origin. Geochim Cosmochim Acta 64: 1945-1964

Mostefaoui S, Zinner E, Hoppe P, Stadermann FJ, El Goresy, A. (2005) In situ survey of graphite in unequilibrated chondrites: Morphologies, C, N, O and $\mathrm{H}$ isotopic ratios. Meteoritics Planet Sci 40: 721-743

Ortega L, Luque J, Barrenechea JF, Millward D, Beyssac O, Huizenga, J-M, Rodas, M (2008) Fluid composition and reactions of graphite precipitation 
in the volcanic-hosted deposit at Borrowdale (NW England): evidence from fluid inclusions. Macla 9: 177-178

Östberg G (2006) Perspectives on research on the formation of nodular graphite in cast iron. Mater Design 27: 1007-1015

Pasteris JD (1989) In situ analysis in geological thin-sections by Laser Raman Microprobe Spectroscopy: a cautionary note. App Spectr 43: 567-570

Pasteris JD (1999) Causes of the uniformly high crystallinity of graphite in large epigenetic deposits. J metamorphic Geol 17: 779-787

Pasteris JD, Wopenka B (1991) Raman spectra of graphite as indicators of degree of metamorphism. Can Mineral 29: 1-9

Pimenta MA, Dresselhaus G, Dresselhaus MS, Cancado LG, Jorio A, Saito R (2007) Studying disorder in graphite-based systems by Raman spectroscopy. Phys Chem Chem Phys 9: 1276-1291

Reich S, Thomsen C (2004) Raman spectroscopy of graphite. Phil Trans Royal Soc London, A 362: 2271-2288

Rumble D, Ferry JM, Hoering TC, Boucot, AJ (1982) Fluid flow during metamorphism at the Beaver Brook fossil locality, New Hampshire. Am J Sci 282: 886-919

Scheele N, Hoefs J (1992) Carbon isotope fractionation between calcite, graphite and $\mathrm{CO}_{2}$ : an experimental study. Contrib Mineral Petrol 112: 3545

Strens RGJ (1965) The graphite deposit of Seathwaite in Borrowdale, Cumberland. Geol Mag 102: 393-406

Sunagawa I (1987) Morphology of Minerals. In Sunagawa I (ed) Morphology of Crystals, Part B. Terra Scientific, Tokyo. pp. 509-587

Sunagawa I (2005) Crystals: Growth, Morphology and Perfection. Cambridge University Press, Cambridge

Tan PH, Dimovski S, Gogotsi Y (2004) Raman scattering of non-planar graphite: arched edges, polyhedral crystals, whiskers and cones. Phil Trans R Soc London, A 362: 2289-2310

Walton AG (1969) Nucleation in liquids and solutions. In Zettlemoyer AC (ed) Nucleation. Marcel Dekker, New York 
Ward JC (1876) The geology of the northern part of the English Lake District. Memoir of the Geological Survey of Great Britain. Quarter Sheet 101SE (England \& Wales Sheet 29, Keswick)

Weis PL, Friedman I, Gleason, JP (1981) The origin of epigenetic graphite: evidence from isotopes. Geochim Cosmochim Acta 45: 2325-2332

Wopenka B, Pasteris JD (1993) Structural characterization of kerogens to granulite-facies graphite: Applicability of Raman microprobe spectroscopy. Am Mineral 78: 533-557 


\section{CAPTIONS OF FIGURES}

Fig. 1 Simplified geological map of the English Lake District (UK) locating the Borrowdale graphite deposit at Seathwaite. The bleached and metasomatically altered zone with the Skiddaw Group at Crummock Water $(\mathrm{CW})$ is also shown

Fig. 2 Morphologies of graphite crystals and aggregates from the Borrowdale deposit. a) Section of a hand sample showing the rounded to elliptical section of the graphite nodules within the altered andesite host rock. Scale is in centimeters. Photos b) to f) are reflected light photomicrographs (one polarizer). b) Detail of the contact (dashed line) between flaky graphite $(F G)$ and cryptocrystalline graphite $(C G)$ in a composite nodule. c) Large arrow points to an encapsulated quartz fragment (dark grey) with small graphite spherulites inside (light grey) embedded in cryptocrystalline (colloform) graphite; note the small graphite ring at the upper left corner of the photo (small arrow). d) Rounded patch of cryptocrystalline graphite (CG) within flaky graphite (FG). e) Colloform graphite (light grey) within the volcanic host rock; note reflectivity zoning parallel to the margins of the graphite aggregate. f) Colloform graphite (light grey) around pyrite (white)

Fig. 3 Morphologies of graphite crystals and aggregates from the Borrowdale deposit. a) Scanning electron microscope image of graphite spherulites disseminated within the volcanic host rock. Photos b) to e) are reflected light photomicrographs (one polarizer). b) The arrow points to a graphite spherulite within flaky graphite. c) Aggregate of graphite spherulites within chlorite. d) Curved and tapering graphite flakes intergrown with chlorite. e) Vermicular graphite intergrown with chlorite. f) Scanning electron microscope image of dish-like graphite

Fig. 4 First-order Raman spectra of the different graphite morphologies from the Borrowdale deposit. a) flaky graphite, b) cryptocrystalline graphite from composite nodules, c) colloform graphite surrounding silicate grains 
within the volcanic host rock (hr), d) colloform graphite surrounding pyrite (py) within the volcanic host rock, e) spherulitic graphite included in encapsulated quartz, f) spherulitic graphite within chlorite (chl)

Fig 5 Reflected light microphotograph (one polarizer) of a composite nodule showing the $\delta^{13} \mathrm{C}$ values of cryptocrystalline (colloform) graphite. The points analyzed by SIMS are indicated by small circles

Fig. 6 Schematic diagram depicting the relationship between supersaturation and growth rate (based on Sunagawa 1987). The type of surface of aggregates and crystals and the nucleation mechanism prevailing in each field (in brackets) are shown. The images correspond to the three main graphite morphologies found in the Borrowdale deposit: 1cryptocrystalline, 2- spherulitic, and 3- flaky

Fig. 7 Phase diagram of the $\mathrm{C}-\mathrm{O}-\mathrm{H}$ system at $600^{\circ} \mathrm{C}$ and $3.5 \mathrm{kbar}$ showing the graphite-fluid isotopic fractionation as a function of fluid composition (modified after Duke and Rumble 1986). Along the graphite saturation curve, for $\mathrm{CO}_{2}$-rich fluids (like fluid $\mathrm{A}$ in the graph), $\mathrm{CO}_{2}$-depletion and/or $\mathrm{H}_{2} \mathrm{O}$-enrichment will result in the precipitation of isotopically heavier graphite. The first mineralizing fluids in the Borrowdale deposit were similar in composition to fluid A (Luque et al. 2009). Conversely, $\mathrm{CH}_{4}$ depletion and/or water-enrichment in $\mathrm{CH}_{4}$-rich fluids (like fluid $\mathrm{B}$ ) will cause the precipitation of isotopically lighter graphite. These qualitative variations of $\Delta_{\text {graphite-fluid }}=\delta^{13} \mathrm{C}_{\text {graphite }}-\delta^{13} \mathrm{C}_{\text {fluid }}$ are relatively insensitive to the exact temperature chosen for the system (Duke and Rumble 1986). For explanation see text 
Table 1 Morphologies and characteristics of graphite from the Borrowdale deposit

\begin{tabular}{|c|c|c|c|c|}
\hline & Morphology & Occurrence & Host & Remarks \\
\hline \multirow{3}{*}{ Aggregates } & Flaky, scaly & $\begin{array}{l}\text { Nodules, irregular } \\
\text { patches, coatings, } \\
\text { disseminations }\end{array}$ & $\begin{array}{l}\text { Altered andesite } \\
\text { and diorite }\end{array}$ & $\begin{array}{l}\text { Randomly distributed } \\
\text { within nodules and } \\
\text { patches (Fig. } 2 \mathrm{~b} \text { ) }\end{array}$ \\
\hline & Spherulitic & Patches & Chlorite & $\begin{array}{c}\text { Individual size of } \\
\text { spherulites ranging from } \\
5-10 \mu \mathrm{m} \text { in diameter } \\
\text { (Fig. 3c) }\end{array}$ \\
\hline & Cryptocrystalline & Patches, colloform & $\begin{array}{l}\text { Altered andesite, } \\
\text { flaky graphite } \\
\text { (composite nodules) }\end{array}$ & $\begin{array}{l}\text { Masses, bands and } \\
\text { "globules" with apparent } \\
\text { reflectance zoning (Figs } \\
2 \mathrm{c}, 2 \mathrm{~d}, 2 \mathrm{e}, 2 \mathrm{f}, 5) \\
\end{array}$ \\
\hline \multirow{7}{*}{$\begin{array}{l}\text { Individual } \\
\text { forms }\end{array}$} & Spherulites & Disseminations & Flaky graphite & $\begin{array}{c}\text { 5-40 } \mu \mathrm{m} \text { in diameter } \\
\text { (Fig. 3b) }\end{array}$ \\
\hline & Spherulites & Disseminations & Altered andesite & $\begin{array}{c}1-5 \mu \mathrm{m} \text { in diameter (Fig } \\
3 a)\end{array}$ \\
\hline & Spherulites & Disseminations & $\begin{array}{l}\text { Encapsulated quartz } \\
\text { fragments }\end{array}$ & $\begin{array}{c}1-3 \mu \mathrm{m} \text { in diameter (Fig } \\
2 \mathrm{c})\end{array}$ \\
\hline & Rings & Disseminations & $\begin{array}{l}\text { Cryptocrystalline } \\
\text { graphite, altered } \\
\text { andesite }\end{array}$ & $\begin{array}{l}\text { Nucleated on silicate or } \\
\text { sulfide grains (Fig. 2c) }\end{array}$ \\
\hline & Flakes & $\begin{array}{l}\text { Graphite-chlorite } \\
\text { intergrowths }\end{array}$ & Chlorite & $\begin{array}{l}\text { Thin curved and } \\
\text { tapering crystals (Fig. } \\
\text { 3d) }\end{array}$ \\
\hline & Vermicular & $\begin{array}{l}\text { Graphite-chlorite } \\
\text { intergrowths }\end{array}$ & Chlorite & $\begin{array}{l}\text { Randomly distributed } \\
\text { within chlorite (Fig. 3e) }\end{array}$ \\
\hline & Disks & Disseminations & Altered andesite & $\begin{array}{l}20-40 \mu \mathrm{m} \text { in diameter } \\
\text { (Fig. 3f) }\end{array}$ \\
\hline
\end{tabular}


Table 2 Raman data for the different graphite morphologies

\begin{tabular}{|c|c|c|c|c|c|c|c|c|c|c|c|}
\hline & $\begin{array}{l}\text { G position } \\
\left(\mathrm{cm}^{-1}\right)\end{array}$ & $\begin{array}{c}\text { D1 } \\
\text { position } \\
\left(\mathrm{cm}^{-1}\right)\end{array}$ & $\begin{array}{c}\text { G FWHM } \\
\left(\mathrm{cm}^{-1}\right)\end{array}$ & R1 & R2 & & $\begin{array}{l}\text { G position } \\
\left(\mathrm{cm}^{-1}\right)\end{array}$ & $\begin{array}{c}\text { D1 } \\
\text { position } \\
\left(\mathrm{cm}^{-1}\right)\end{array}$ & $\begin{array}{l}\text { G FWHM } \\
\left(\mathrm{cm}^{-1}\right)\end{array}$ & $\mathbf{R} 1$ & $\mathbf{R 2}$ \\
\hline Flaky & & & & & & Colloform (silicate) & & & & & \\
\hline Mean value & 1581 & 1350 & 20 & 0.04 & 0.06 & Mean value & 1582 & 1355 & 27 & 0.23 & 0.25 \\
\hline Std dev & 1.2 & 2.5 & 2.9 & 0.09 & 0.09 & Std dev & 1.7 & 2.8 & 2.5 & 0.09 & 0.09 \\
\hline Number of analyses & 25 & & & & & Number of analyses & 28 & & & & \\
\hline Cryptocrystalline & & & & & & Colloform (pyrite) & & & & & \\
\hline Mean value & 1581 & 1355 & 21 & 0.09 & 0.05 & Mean value & 1583 & 1356 & 26 & 0.26 & 0.28 \\
\hline Std dev & 1.3 & 2.3 & 1.5 & 0.02 & 0.08 & Std dev & 1.0 & 2.4 & 2.2 & 0.08 & 0.07 \\
\hline Number of analyses & 17 & & & & & Number of analyses & 12 & & & & \\
\hline Spherulitic & & & & & & $\begin{array}{c}\text { Vermicular } \\
\text { intergrowth (chlorite) }\end{array}$ & & & & & \\
\hline Mean value & 1582 & 1356 & 20 & 0.07 & 0.06 & Mean value & 1580 & 1351 & 21 & 0.11 & 0.16 \\
\hline Std dev & 0.9 & 3.2 & 1.5 & 0.07 & 0.09 & Std dev & 1.3 & 3.0 & 1.5 & 0.06 & 0.07 \\
\hline Number of analyses & 15 & & & & & Number of analyses & 18 & & & & \\
\hline
\end{tabular}

G FWHM: Full width at half maximum of the $G$ band 
Table 3 Results of the ion probe analysis (SIMS) of graphite morphologies. The $\delta^{13} \mathrm{C}$ values are relative to the PDB standard

\begin{tabular}{|c|c|c|c|c|c|}
\hline $\begin{array}{l}\text { Vermicular intergrowths } \\
\text { in chlorite }\end{array}$ & $\begin{array}{l}\delta^{13} \mathrm{C} \\
(\%)\end{array}$ & Cryptocrystalline & $\begin{array}{l}\delta^{13} \mathrm{C} \\
(\%) \\
\end{array}$ & Flakes & $\begin{array}{l}\delta^{13} \mathrm{C} \\
(\% 0)\end{array}$ \\
\hline F2@1.asc & -34.87 & P0@1.asc & -33.72 & P0@17.asc & -29.26 \\
\hline F2@2.asc & -33.76 & P0@2.asc & -32.56 & P0@18.asc & -31.89 \\
\hline F2@3.asc & -33.99 & P0@3.asc & -34.45 & P0@19.asc & -28.97 \\
\hline F2@4.asc & -35.29 & P0@5.asc & -34.09 & P0@20.asc & -28.65 \\
\hline F2@5.asc & -34.20 & P0@6.asc & -34.45 & P0@21.asc & -29.72 \\
\hline F2@6.asc & -35.20 & P0@7.asc & -33.87 & P0@22.asc & -28.71 \\
\hline F2@7.asc & -35.15 & P0@8.asc & -33.60 & & \\
\hline F2@8.asc & -33.92 & P0@9.asc & -31.60 & G2C@1.asc & -30.85 \\
\hline \multirow[t]{2}{*}{ F2@9.asc } & -34.05 & P0@10.asc & -32.10 & G2C@2.asc & -31.31 \\
\hline & & P0@11.asc & -34.29 & G2C@3.asc & -30.56 \\
\hline AVERAGE & -34.49 & P0@12.asc & -35.12 & G2C@4.asc & -31.01 \\
\hline \multirow[t]{2}{*}{ Standard deviation } & 0.62 & P0@13.asc & -34.01 & G2C@5.asc & -30.75 \\
\hline & & P0@14.asc & -32.87 & G2C@7.asc & -30.23 \\
\hline Spherulites in chlorite & & P0@15.asc & -34.01 & G2C@8.asc & -30.22 \\
\hline F2@11.asc & -29.87 & P0@16.asc & -34.73 & G2C@9.asc & -28.97 \\
\hline F2@12.asc & -30.02 & & & G2C@10.asc & -31.55 \\
\hline F2@13.asc & -30.98 & AVERAGE & -33.70 & G2C@12.asc & -31.61 \\
\hline F2@14.asc & -29.76 & Standard deviation & 1.00 & & \\
\hline F2@15.asc & -31.11 & & & AVERAGE & -30.26 \\
\hline F2@16.asc & -29.18 & & & Standard deviation & 1.10 \\
\hline AVERAGE & -30.15 & & & & \\
\hline Standard deviation & 0.75 & & & & \\
\hline
\end{tabular}



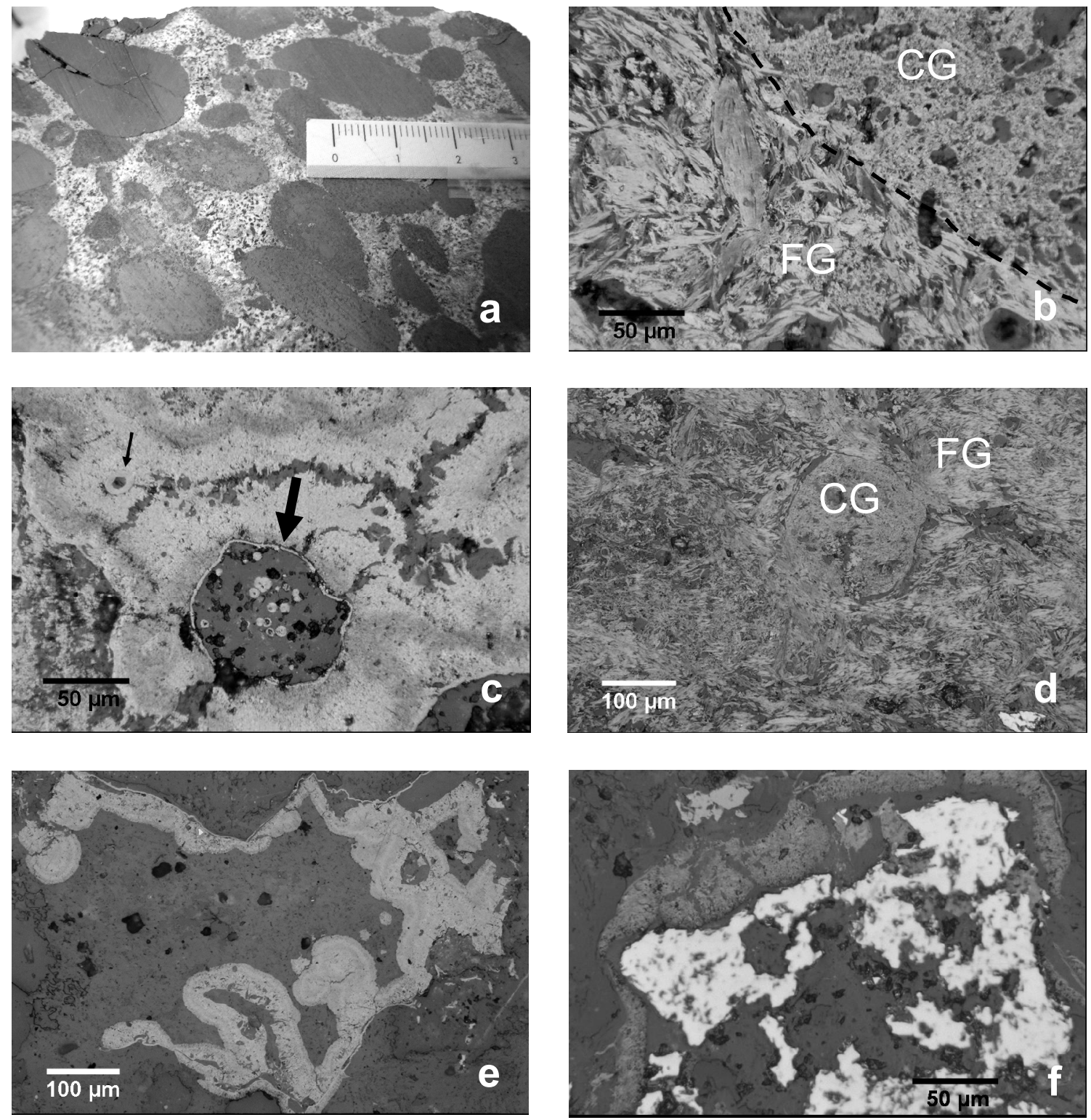

Fig.2 

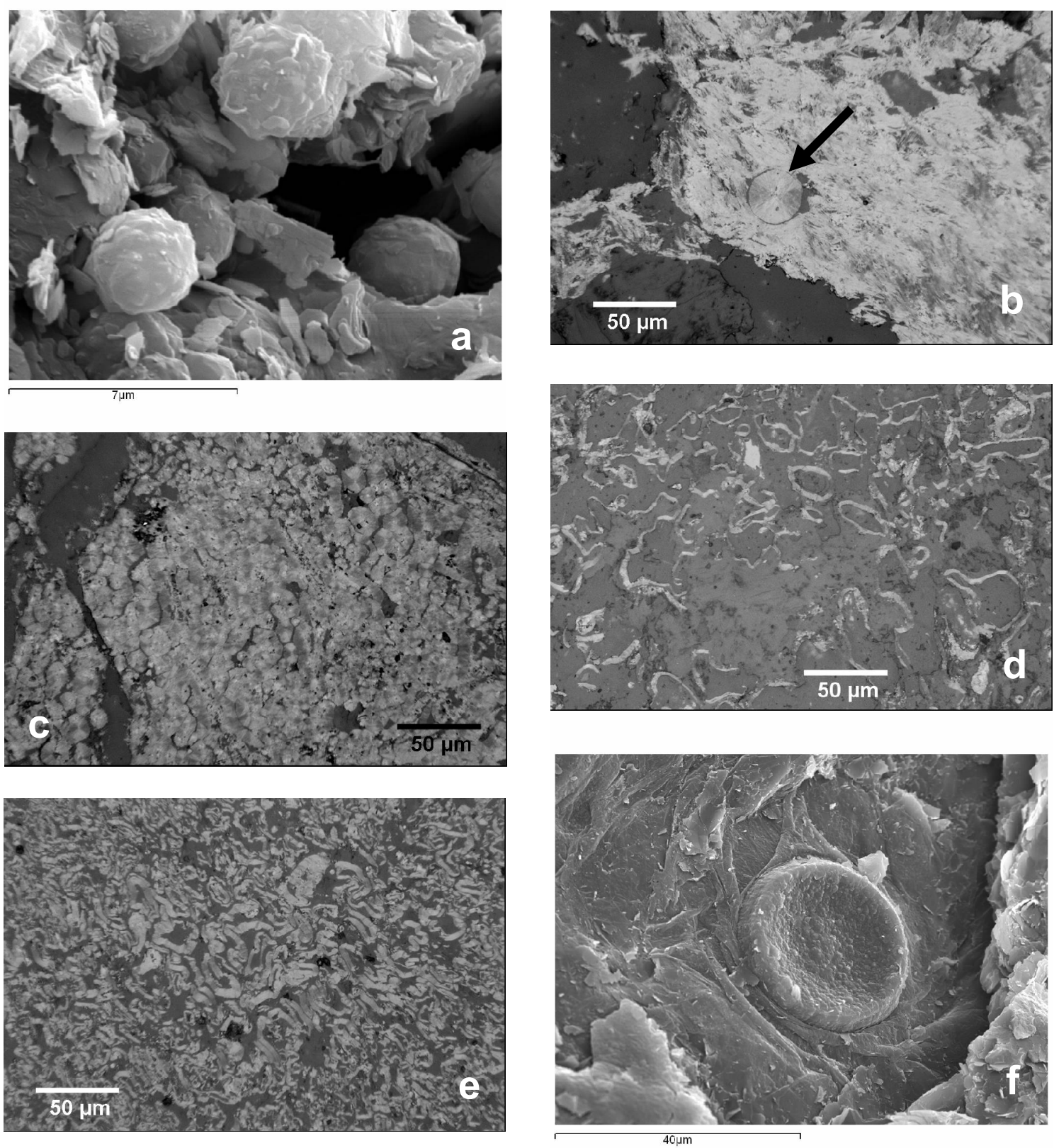

Fig.3 


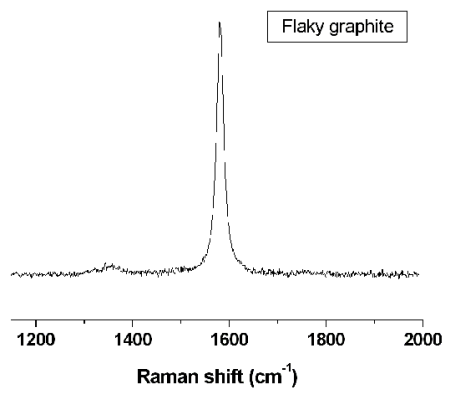

a)
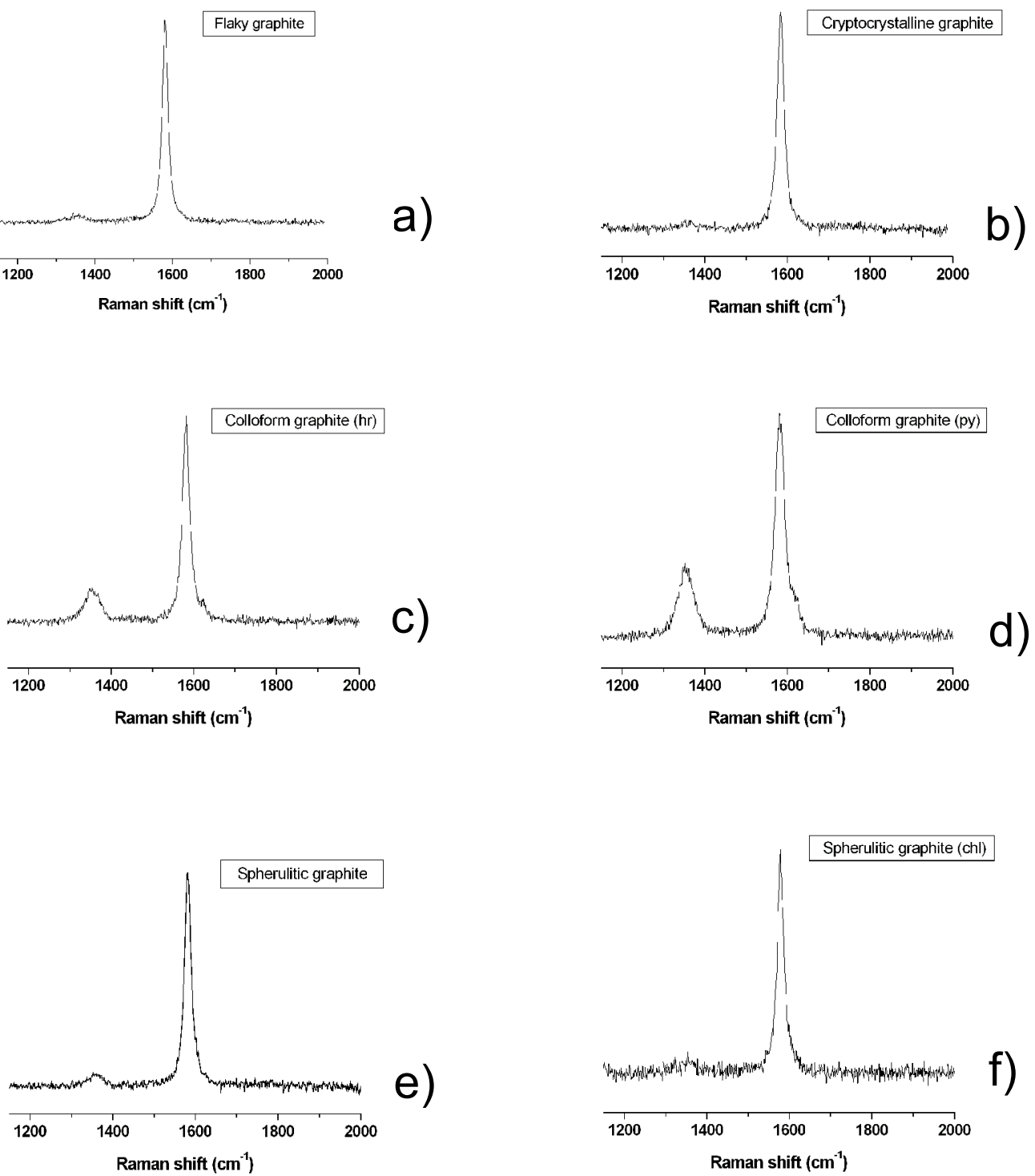

Fig. 4 


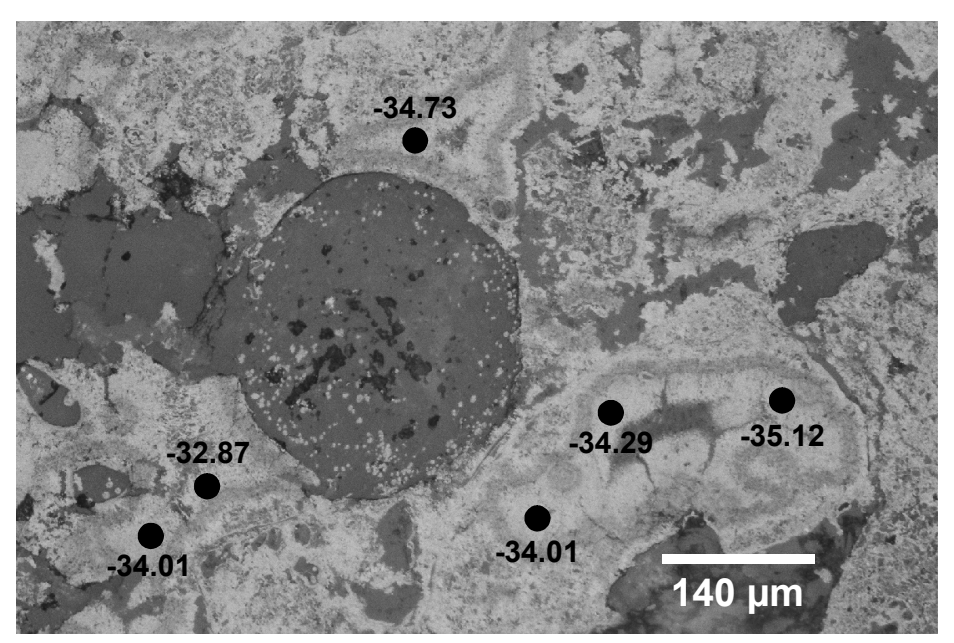

Fig. 5 


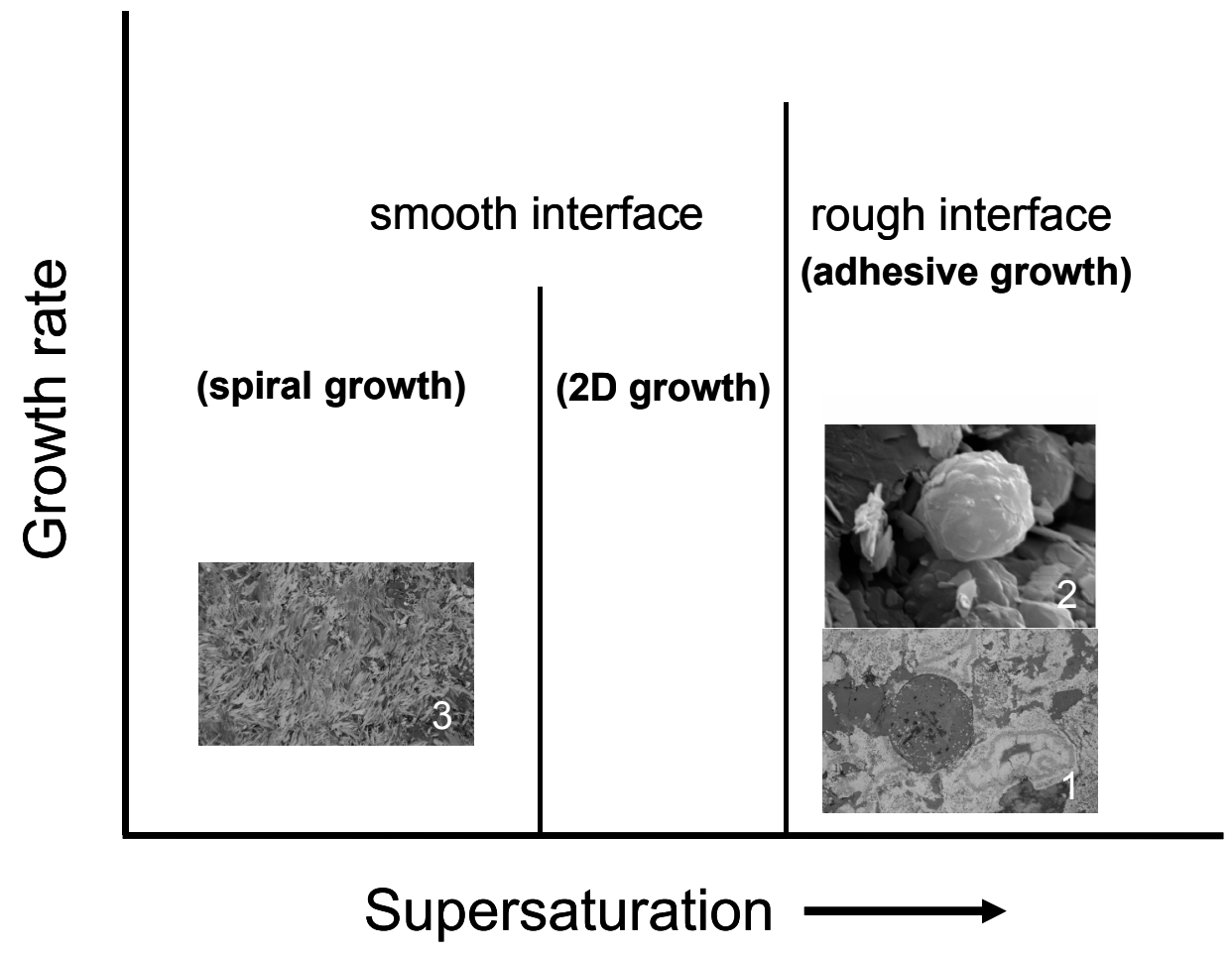

Fig. 6 

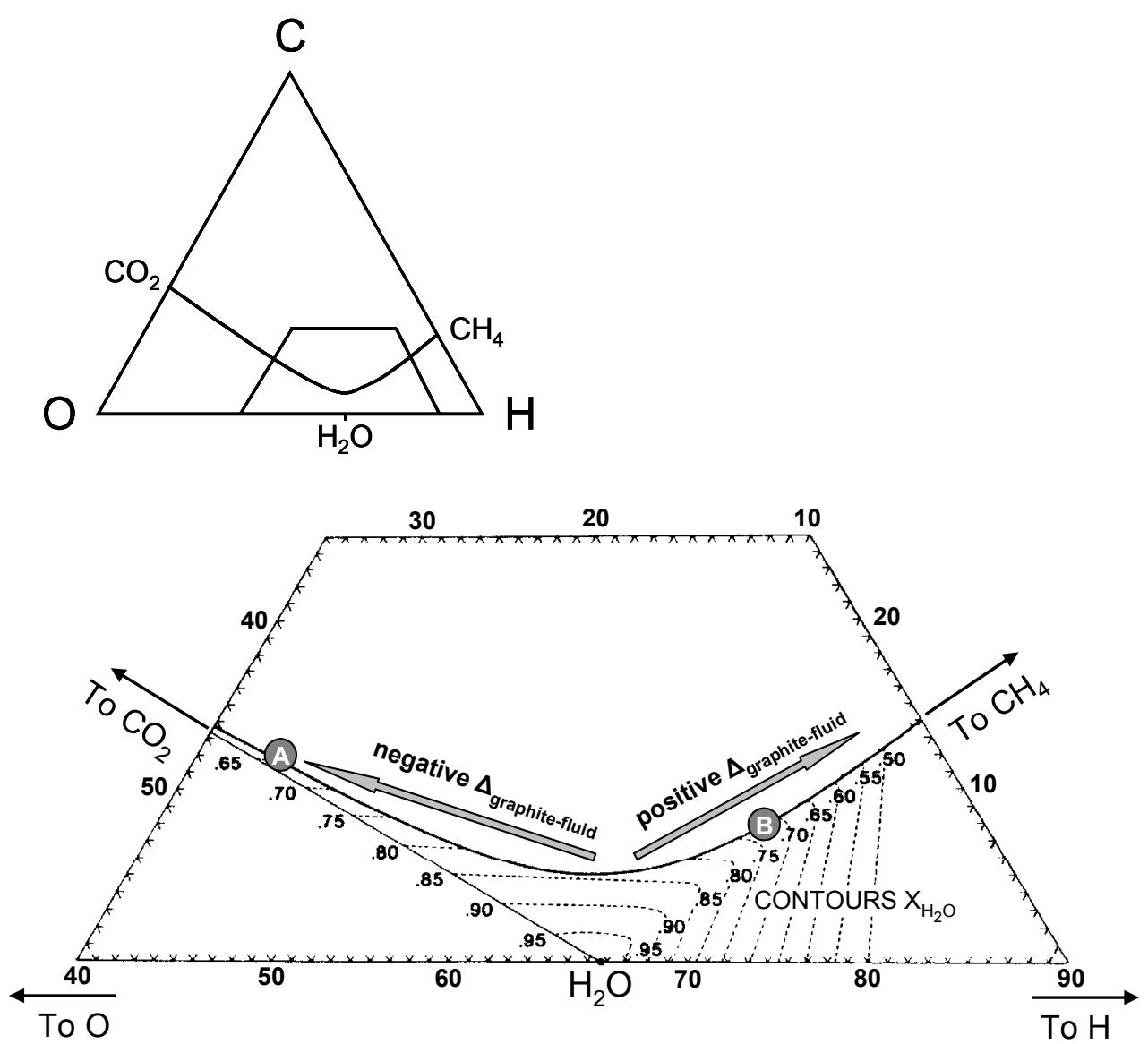